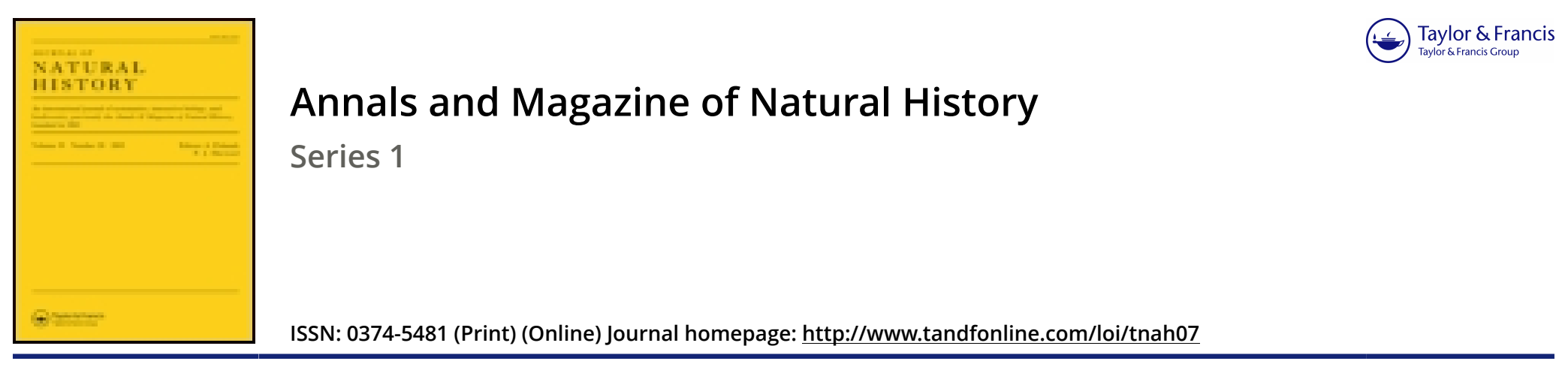

\title{
III.-Botanical notes of a tour in Ireland, with notices of some new British plants
}

\section{J. Ball Esq.}

To cite this article: J. Ball Esq. (1838) III._Botanical notes of a tour in Ireland, with notices of some new British plants, Annals and Magazine of Natural History, 2:7, 28-36, DOI: 10.1080/00222933809496648

To link to this article: http://dx.doi.org/10.1080/00222933809496648

曲 Published online: 15 Mar 2010.

Submit your article to this journal \lceil

Q View related articles $₫$ 
Petromyzon Planeni, Cuv. Fringed-lipped Lamprey.I am indebted to Mr. R. Ball for two specimens of this fish, which were obtained in the vicinity of Naas, county of Kildare. They are $4 \frac{1}{2}$ and 5 inches in length respectively; the smaller one only has the "anal sheath," which is two lines long. (See fig. in Yarr. B. F. vol. ii. p. 457.) The dentition in these specimens is similar to that shown in Mr. Yarrell's figure of $P$. fuviatilis, and consequently in this character they do not accord with his figure of the mouth of P. Planeri; in this same wood-cut however, the chief peculiarity of the species-the fringed lip-is well represented. The dentition or "armature of the mouth" of $P$. fuviatilis and P. Planeri is similar, as remarked by Mr. Jenyns*.

April 2, 1838. From the Rev. Charles Mayne, Vicar General of Cashel-to whose kindness I have in several instances been indebted for specimens of fishes, \&c., from the river Shannon-I to-day received a lamprey, $4 \frac{3}{4}$ inches in length, recently taken in the vicinity of Killaloe, and which proved to be the $P$. Planeri.

\section{Addendum to vol. i. p. 356.}

Goвius Gracilis. Dublin, June 1838.-In the collection of my friend Robert Ball, Esq. of this city, there are two specimens of Gobius gracilis about 3 inches in length, from Youghal. On closely comparing them with individuals of Gobius minutus of equal size, the differences in so far as they are above mentioned are very obvious ; but further, as in those before examined, I cannot perceive any constant characters.

1II.-Botanical Notes of a Tour in Ireland, with Notices of some new British Plants. By J. BALL, Esq., of Christ College, Cambridge.

THE attention of British naturalists having been recently directed towards the wide field for investigation which Ireland presents to them, it may perhaps not be inappropriate to offer some additional information for the botanical tourist, gathered

* Dublin, June 1838. - Specimens of this Lamprey have lately been received by R. Ball, Esq. from Inch river, about ten miles north-west of Youghal. 
during an excursion from Dublin through the northern part of the island in the summer of 1837 ; as also to notice the discovery of two or three plants, which are, I believe, new to the British Flora. The neighbourhood of Dublin is principally rich in some of the more local sea plants; I may mention as a station for several of these the south-eastern side of the rocky point of Killiney Hill, which runs out towards the small island of Dalkey. I have here gathered Inula (Limbarda, Hook.,) crithmoides, Lavatera arborea, Euphorbia portlandica, Linum angustifolium, Statice spathulata, Daucus maritimus, \&c. Further south, near Bray, Marrubium vulgare may be seen more truly wild than it usually is in Ireland, extending for some distance along the shore, as also upon the common near the town: on banks near the road, between Bray and Enniskerry, Erodium moschatum appears certainly indigenous, and near the latter village I have noticed Melissa Calamintha (Calamintha officinalis, Hook.), and Polygonum minus, Scirpus Savii, Habenaria chlorantha, \&c., as also Geranium pyrenaicum certainly wild and very common. Eriophorum pubescens, which has hitherto been found in the boggy ground just above the village, is, I fear, extirpated by drainage. In the sand pits on the hill by the Dublin road may be noticed Festuca bromoides, and also a remarkable state of Hieracium Pilosella, apparently intermediate between that plant and H. Pcleterainum, Merat., which latter is however by many botanists considered a mere variety of $H$. Pilosella.

In Glen Cree, a valley running from Powerscourt to Lough Bray, I have gathered Carex lavigata, Senecio viscosus, Pinguicula lusitanica, Myosotis repens, Pyrus Aria, \&c.; and on the mountains south of Glen Cree $I$ have found a Leontodon (Apargia, Hook.), to all appearance distinct from any recognised British species. If it be possible to judge by mere descriptions in this difficult genus, I should consider it to be L. alpinum, Jacquin, (L. pyrenaicum, Gouan, though in some respects it approaches more near to L. hastile of Linnæus.

The neighbourhood of Powerscourt Waterfall is remarkably productive in ferns; in addition to the common species, there are found here Polypodium phegopteris, Nephrodium oreopteris, Hymenophyllum Tunbridgiense and H. Wilsoni (which latter 
is not rare on the Irish mountains), and here for thirty years has been known to grow a single frond of the rare Trichomanes brevisetum. On the south side of the stream, below the waterfall, and elsewhere in the same neighbourhood, grows a species of Nephrodium which Mr. Mackay considers identical with $N$. dumetorum of Smith. The plant however by no means agrees with the specimen in Smith's Herbarium, which is nothing but a small diseased specimen of $N$. dilatatum. The present specimen differs widely from any of the forms of that variable plant which I have seen; how far these differences may be permanent is of course a question to be determined by more experienced botanists than myself. Near the same place I have observed a concave variety of a Nephrodium of the spinulosum tribe*, which may possibly be the same as the variety of $N$. dilatatum mentioned by the Rev. W. Bree in Mag. Nat. Hist. vol. iv., though it differs very constantly both in form and habit from that plant. I have found it also on the Great Sugar Loaf in the County of Wicklow and on Curslieve Mountain in Mayo.

Salix herbacea may be gathered on rocks at the summit of Djouce mountain, and is, I believe, found in similar situations on other mountains of this group. Upon the great Sugar Loaf, which, like other mountains composed of quartz rock, is exceedingly unproductive both in animal and regetable life, almost the only plant of interest is the Melampyrum montanum, Johnstone. This plant, which I have met in a similar situation on Curslieve in Mayo, is found by the side of the largest gully on the east side of the mountain; it preserves very constantly its distinct habit. I am not aware whether it has ever been remarked that the form of the lowest pair of leaves is always obovato-lanceolate, being quite different from that of the superior ones. In boggy ground, at the north-east base of the mountain, grows the Wahlenbergia (Campanula, L.) hederacea, mentioned by Mr. Mackay as growing upon this mountain. In the Dargle, near the bed of the river, may be found Meconopsis cambrica, and Bromus giganteus $\beta$, and

* The name spinulosum appears more applicable to this than to any plant of this genus, the serratures of the pinnules being all tipped with stifl' hairs, which converge towards the extremity of each pinnule. 
Bryum punctatum abundant in fructification. Returning to Dublin, and proceeding northward along the shore of the bay, Linum angustifolium may be found plentifully on banks between Clontarf and Howth; on the sandy sea shore Euphorbia paralia is abundant. Close to the ruined church of Kilbarrick may be seen the five British species of Papaver, P. somniferum being as truly wild as it is ever seen in Britain. In addition to many rare or local plants mentioned by Mr. Mackay I have found in the sandy fields near this spot, Bromus erectus, Festuca rubra, and Avena pubescens, and in a marsh near Baldoyle, Heliosciadium inundatum. On banks above the village of Howth I have collected a species of Sagina, differing in appearance from the described British species, and agreeing very closely with a specimen from Sussex, named by Mr. Borrer the Sagina filiformis of Pourret. For many rare plants in the neighbourhood of Portmarnock, stations are given in Mackay's Flora Hibernica : I may observe that the species of Viola, named in that work $V$. Curtisii, and which agrees with cultivated specimens from a plant so named by $\mathrm{Mr}$. Borrer, is not the $V$. Curtisii of the original description, which agrees with $V$. lutea in having the centre lobe of the stipules undivided, being probably no more than a variety of that plant; whilst the plant in question, which is abundant on the sandy coasts north of Dublin, and which I have seen also in the counties of Down and Derry, is apparently very nearly allied to the $V$. saxatilis of continental writers, which in common with all the many named forms of $V$. tricolor, has the middle lobe of the stipule dentate. On the sandy warren near Portmarnock I noticed a tetrandrous species of Cerastium, which appears to be identical with the C. pedunculatum, described and figured by Mr. Babington in vol, ii. p.197. Pl. VI. of the Magazine of Zoology and Botany. I may mention having noticed in the county of Dublin the Fumaria parvifora, for which only a single station is given in the 'Flora Hibernica.' At Clogher Head, in the county Louth, I found in a corn field, just above the village, Thlaspi arvense and Lamium incisum, both rare in Ireland; and on the summit, Trifolium striatum and Trigonella ornithopodioides; and on steep banks over the sea Statice spathulata and a white väriety of Anthyllis vulne- 
raria, first found, I believe in Kerry, by Miss Hutchins. Near this I likewise found Fedia auricula, and, which is quite as rare in Ireland, Lepidium campestre, the place of which plant, so familiar to the English botanist, is almost always filled in this island by $L$. Smithii. I may mention that the distinctive character drawn from the smoothness of the capsule in $L$. Smithii, though very general, cannot be relied upon, the only constant character being, as I believe, the comparative length of the styles. At Jonesboro', near Dundalk, I observed a white-flowered variety of Galeopsis Tetrahit, the same I believe with the var. $\beta$ pubescens of Henslow's Catalogue of British Plants; it has the leaves of a more acutely lanceolate form, and the whole plant has a softer and more abundant pubescence.

I may here mention that near Newcastle in the county Down, the rare Achillea tomentosa has been found by Miss Keown. Sir J. E. Smith mentions his having received this plant from Ireland, but no station has before been made known for it in that country. The neighbourhood of Belfast is peculiarly rich in botanical productions, to the stations for many of which I was directed by my friend Professor Bryce. I may mention some additional objects of interest which have not, I believe, been previously noticed. On the south side of the bay, between Belfast and Hollywood, I found Atriplex littoralis, Blysmus rufus, and Scirpus glaucus. By the side of a sandy lane, to the right of the road to Hollywood, I remarked a singular straggling variety of Viola lutea, which plant is very rare in Ireland. Here also may be found the Rosa Hibernica, which has become very scarce in this neighbourhood. Upon that interesting botanical station the Cave Hill, I found a late single-flowered variety of Saxifraga hypnoides, the flowers of which were mostly sessile upon the extremities of the procumbent shoots; some, which had elongated flower stalks, appeared identical with the form described by Smith under the name of elongella: together with this, upon the south side of the hill, I found the Alchemilla vulgaris $\beta$ minor (A. hybrida, Pers.) ; it appears to differ in nothing from $a$ but in its small size and dense white spreading pubescence, which gives it a hoary appearance. The finest specimens of the rare Orobanche mibra (some of them nearly a foot in height) are to be found 
on the basaltic rocks at the south-east angle of the hill. Under bushes at the east side I found Circa a intermedia very luxuriant both in flower and fruit, as likewise Vicia sylvatica, \&c. At Colin Glen, a few miles from Belfast, I gathered specimens of Rubus saxatilis; and in boggy ground, about half way up the Glen, a single specimen of a fern which corresponds accurately with Smith's original specimens of Nephrodium cristatum (N. callipteris, $D C$.). Nearly in the same place I collected Mentha rubra and a Galium, apparently of the palustre tribe, but without flower or fruit, remarkable for the leaves in the whorl being constantly four in number. In ascending from the lower woody part of the glen to the rocks at the summit, the botanist can scarcely fail to remark the gradual transition from a very divided form of Aspidium angulare through the forms named aculeatum and lobatum, to one on the rocks above, which cannot be distinguished from A. lonchitis*. Throughout a great part of Antrim I noticed Rubus Idcus as the most common species of the genus in hedges and woods as also on rocky ground.

At Coleraine in Derry, Carum verticillatum is found in great abundance by the west bank of the river about a quarter of a mile below the town. In a potato field near the same place I found Lamium intermedium, which is new to the Irish Flora; I also found it in a similar situation near the foot of Ben Bulben in Sligo, and it is probably not rare in the northern counties. On sandy ground, near the mouth of the Baun, I noticed Gnaphalium minimum and rectum, and Trifolium medium. I may direct the attention of the conchologist to the sandy coast of Magilligan, which is very productive in marine shells. In addition to many rare plants mentioned in the Flora $\mathrm{Hi}$ bernica as growing on Ben-ye-venagh, I found many alpine species not common in Ireland, Silene acaulis, Dryas octopetala, Saxifraga hypnoides, Salix herbacea; and on Umbragh rocks Rubus saxatilis. Throughout the counties of Derry, Tyrone, Donegal, and Sligo Galiopsis versicolor is common; but I may observe as somewhat remarkable, that I have never

* In this glen some rare land shells, Helix fusca and scarburgensis (lamellata, Drap.), are to be found : for the direction to this spot 1 am indebted to that active naturalist $\mathrm{Mr}$. Thompson of Belfast.

$$
\text { Ann.Nat.Hist. Vol. 2. No.7. Sept. } 1838 .
$$


seen it except in potato fields; a fact somewhat corroborative of the opinion as to its being a luxuriant variety of G. Tetrahit. In the neighbourhood of Enniskillen, on the banks of Lake Erne, I found Circa intermedia and Galium boreale; and in the same locality many species of Mentha might probably be discriminated by a botanist acquainted with that difficult genus. Perhaps the mountains of Sligo offer the most promising field to the inquiring naturalist of any part of Ireland. I may mention the results of a hurried visit to Ben Bulben, which is already known to be a habitat of Arenaria ciliata and many other rare plants; on the limestone ledges at the north-west angle of the mountain I found Dryas octopetala, Silene acaulis, Saxifraga hypnoides and Aizoides, Juniperus nana, and a very diminutive variety of Thalictrum minus, which has possibly been mistaken for $T$. alpinum, said to grow on this mountain. A little to the east, on the northern face of the rock, I gathered a very large glabrous-fruited form of Carex recurva, probably the C. Micheliana of Eng. Bot., and in the same spot Polygonum viviparum, not mentioned in the Flora Hibernica; but in a notice in the Mag. Nat. Hist. since pointed out to me, I find that it was gathered nearly in the same spot many years ago by Mr. Murphy. Proceeding eastward along the ledges of limestone, which abound in fossils, particularly many species of corals, I found growing in company with Sesleria coerulea a grass new to the British Flora, the Koleria valesiaca, Gaud. Near the same place I noticed Asplenium viride, Cystopteris fragilis, \&c. On the bogs between Sligo and Ballina I gathered Gnaphalium restum, Osmunda regalis, and Juncus nigritellus, Eng. Bot. Supp., a plant apparently quite distinct from $J$. lamprocarpus; and near the coast Raphanus maritimus and Scirpus Savii, $\beta$. monostachys, a form which I have also noticed in Wicklow. Near Ballina Gentiana Amarella occurs with white flowers. In the great boggy district of Tyrawley, the herbage consists principally of Rhyncospora alba, Schonus nigricans, Eleocharis palustris, Drocera anglica, and Osmunda regalis, with a few of the more common carices and junci. After passing the night at a cottage about seven miles from its base, I next day ascended Curslieve, one of the highest mountains in the Erris group. By the side of a stream, descend- 
ing from Currough-na-Gorragh, a small lake at a considerable elevation on the mountain, I gathered Melampyrum montanum, and a concave Nephrodium which I have already mentioned. I also found here a species of Epilobium with downy fruit somewhat allied to E. alpinum ; it corresponds accurately with the description of E. nutans in Reichenbach's 'Flora Excursoria Germanica,' and Professor Don considers it identical with that plant. On the rocks above Currough-na-Gorragh I observed a variety of Saxifrag a stellaris with a large spreading panicle, the leaves covered with long dense hairs larger and more deeply cut than in the ordinary state of the plant. Saxifraga umbrosa $\beta$. (S. punctata, Haworth), is abundant on this and all the other mountains in this part of Ireland. Between Newport and Castlebar I noticed Nepeta Cataria, probably not indigenous, growing to the height of three or four feet. The limestone district on the banks of Lake Carra near Castlebar, is exceedingly productive in rare plants ; on the north-eastern shore near Moore Hall I found Gentiana verna in fruit, a dwarf red-flowered variety of Gentiana Amarella, Gnaphalium dioicum, Thalictrum minus, sometimes growing to a large size and approaching very near to T. majus, Galium boreale in great luxuriance, \&c. To the west of this point I found Neottia spiralis and Equisetum variegatum. On a point of low rocky land called Derrynany, I found Rhamnus catharticus and frangula, both very rare in Ireland; Rubia peregrina, Euonymus europceus, and a fern in abundant fructification but with the capsules all burst, probably a Nephrodium, in which case it is allied to $N$. thelypteris, but differs in its very rigid habit, and in having the pinnules finely serrated and wanting the characteristic depression of the two lower pinnæ.

Near Delphi in Morrisk I noticed Lycopodium selaginoides with Saxifraga umbrosa, and Daboëcia (Menziesia, Sm.) polifolia in great abundance, as also Anthemis nobilis, which is a rare plant in Ireland. In a walk across the district lying between the Manturk mountains and the group called the Twelve Pins, I gathered several of the peculiar plants of this district, as Eriocaulon septangulare, Utricularia minor and intermedia, \&c.: also on rocks in the bed of the river above Lough Inagh, Galinm boreale, Thalictrum minus, and Hiera- 
cium umbellatum, in a very reduced state and generally with only a single flower to each stem. An account of the botany of Connamara having been published by my friend $\mathrm{Mr}$. Babington in vol. ii. of the Mag. Nat. Hist., it will be unnecessary to add anything further as to this district. On the limestone rocks at Kilcornan near Galway, I collected Grammitis ceterach, Melissa Calamintha, Asperula cynanchica, Euonymus europaus, Saxifraga tridactylites, \&c.; also, which may appear somewhat remarkable, on level ground near the sea, $J u$ niperus nana in great abundance and luxuriance.

$\mathrm{I}$ cannot close this brief notice without expressing my obligations to my friend Mr. Babington for his assistance in the determination of many of the plants here mentioned.

It is hoped that these results of a very hurried visit to some little frequented parts of Ireland, may tempt some British naturalists to bestow a more careful examination on the hitherto little investigated districts of the west, where there can be no doubt that much would be found to repay their exertions.

\section{IV.-Some Account of the Genus Langsdorffia. By G.W. Aryott, Esq., LL.D. \\ LANGSDorffia Mart.}

Receptacula solitaria, stipites simplices terminantia, unisexualia. Flores MascuLI inter paleas clavatas basi complanata in favi modum nexas sessiles. Perigonium infundibuliforme, limbo 3-5-fido, laciniis restivatione induplicato-valvatis. Stamina 3-5, monadelpha, perigonii laciniis opposita; columna solida, tubo perigonii adnata, parte libera anthesis breviore: antheræ connatæ, cxtrorsæ, biloculares; loculi æquales, juxta totam longitudinem dehiscentes. Ovarii rudimentum nullum. Flores FemineI (imperfecti?), confertissimi, pedicellati. Stylus filiformis simplex. Ovarium stipitatum in stylum gracilem atteuuatum. Herbæ carnose, stipites e rhizomate hypogao crassiusculo assurgentes, simplices, squamis obsessi, monocephali. Capitula unisexualia, alia ex eoden shizomate mascula, alia feminea.

1. L. janeirensis; rbizomate repente subsimplici, stipitis squamis arcte imbricatis lanceolatis villoso-fimbriatis, perigonio masc. trifido laciniis demum patentibus, floribus fem. (glandulam nullam ambientibus?) infra stylum bulboso-granulosis.-L. janeirensis, L. C. Richard, in Mem. du MTus. d'Hist. Nat. viii. p. 412, t. 19.-L. hypogæa, Mart. Journ, von Brasil, ii. p. 179 ; Nov. gen. et sp. iii. p. 181. t. 299.

$\mathrm{Hab}$. in sylvis umbrosis circa Rio Janeiro.

As no notice is taken of the glands which in the next are 